\title{
Gender and Leadership Differences: Reality or a Dilemma?
}

\author{
Prem Raj Bhandari \\ (Lecturer), Kailali Multiple Campus Dhangadhi, Kailali
}

\begin{abstract}
Gender is a wide spread issue in the world. Male domination and oppression, gender biasness, gender discrimination, and gender stereotypes are the main issues that are related to gender discussion. In developing countries gender is in the worst forms. In this context, this article aims to assess the gender differences in educational leadership in Nepal. For this, purposive sampling was used and two female principals from public and private schools each were taken as the sample. Intensive interviews were conducted with the principals and data were gathered. Discussions are based on literatures and two theories- radical feminism and symbolic interactionism. It is found that females had different experiences from the beginning of childhood and later these experiences had resulted different behaviour, working style and perspectives about self and about the world. These factors made females different than males. Because of gender discrimination and gender biased behaviour of the society female principals has to face many challenges and problems in their field.
\end{abstract}

Keywords: feminism, symbolic interactionism, gender stereotype, safe-zone, oppression.

DOI: $10.7176 / \mathrm{JEP} / 10-1-10$

\section{Introduction}

Gender is a social construct. For a long time, researchers have been paying their attentions in gender and its effects on social life as well as leadership roles. Still there are dilemmas on how gender creates differences in human perception and their behavior. Mostly gender perspective concerns itself on the differences between males and females.

Usually gendered behaviors are seen in patriarchic society, where 'sex role stereotypes', gender discriminations, gender biasness, different forms of oppressions etc. are common (Adkinson, 1981; Coleman, 1996; and Bista \& Carney, 2001). Such phenomena are in different forms in different societies for a long.

In educational leadership, females underrepresentation is seen everywhere (Abdulkareem, Saeed, Umaru \& Yekeen, 2011; Adkinson, 1981; Bista, 2006; Bista \& Carney, 2001; Coleman, 1996; Helterbran \& Rieg, 2004; Hoff, Menard \& Tuell 2006). Even in developed countries as Norway, Sweden, Finland, and the United States females are underrepresented in higher leadership position and in Europe; females lead only 3\% in top 50 companies (Hillier, 2012).

In developing countries as South Africa, Israel, United Arab Emirates, Qatar, and Saudi Arabia the scenario is worse (Hillier, 2012). In Nepal the percentage of female school principle was 3.4\%, $1.3 \%$ and $3.7 \%$ in primary, lower secondary and secondary level respectively (Bista \& Carney, 2001). In Nigeria, $7 \%$ and $9 \%$ females were administrative heads in two states (Mohajeri, Mukhtar \& Balash, 2015).

These are some of the examples of females' participation in higher leadership positions. The 'stereotypic' concept assumes that females are weaker, soft hearted, weak in decision making, weak in discipline maintaining, more sentimental, more sensitive, unable to do hard decisions and so on (Bista, 2006; Sandra \& Sandra, 2007). Another 'glass ceiling' concept also plays vital roles on self perception of females (ibid). This is the psychological perspective on self. "The term 'glass ceiling' refers to the way in which women themselves have internalized a patriarchal gender ideology which, when acted out, undermines their own chances at securing leadership positions" (Hillier, 2012, p. 26).

Gender based socialization, gender discrimination; unsupportive homely environment, male dominated culture in the organization, lack of role models or mentors, racial discriminations, lack of encouragement etc. are the barriers for female leadership. Researchers argue that females give more priority to the family than the organization (Kellerman \& Rhode, 2007; as cited on Hillier, 2012). This responsibility limits the mobility of the females which is also becomes a barrier to them (Leatherwood \& Williams, 2008). They have to bear the responsibility of children and spouse, and this affects their carrier path.

Many of the literatures argue that women are excluded from social networks, which is one of the most significant aspects of organizational power. On the leadership role, the social network and social relation is mostly needed but being busy on house hold responsibilities, usually female loss the social network (Hillier, 2012; Sandra \& Sandra, 2007). Responsibilities of private life, lack of family support, sexual discrimination, difficult working condition, and long lasting effects of sexiest social values are the reasons why females do not like to hold administrative posts (Kosar, Altunay \& Yalcinkaya, 2014).

From the very beginning of the childhood boys and girls treated and socialized differently. Professions or occupations are divided on gender basis. Professions are divided into masculine and feminine (Barbulescu \& Bidwell, (2013) Mainly girls prefer so-called easy professions and boys prefer challenging and tuff professions. 
Researchers have shown that from few decades the number of female participation on leadership roles is increasing gradually but this is not due to the policy implementation or capacity building process. Feminists have developed the theory of "gendered job queues".

Gendered job queue theory argues that the most valued jobs are reserved for the men of the dominant racial ethnic group. Once these positions are no longer valued or begin to provide decreased wages, dominant men exit from the position creating opportunities for women or men of disadvantaged racial ethnic groups (Reskin, 2002, as cited in Hillier, 2012. p. 15).

Some researcher found that females have different leadership styles than that of males. They apply democratic, participative and collaborative style; they are more nurturing and less autocratic (Burdick \& Danzig, 2006). Many females who have leadership roles seem to be successful leaders. Even the society is doubtful for the females' leadership. Successful females are assumed successful because they had masculine style of leadership. "This view is "double bind" dilemma and as the "think-leader-think-male" stereotype" (Hillier, 2012, p.39).

Nearly half of the world's population covers females and half of the teaching force covers females but the access of females in higher level educational leadership role is far behind than that of males. Are females really incapable to perform the educational leadership roles? Do they reject the responsibility of educational leadership roles? Does the society trustless on the educational leadership of females? Do females have different leadership styles than males? If so, what makes them different?

\section{Theoretical Framework}

Usually it is claimed that males and females have different leadership styles. Males are supposed- influential, quick decision makers, skilled in time utilization, discipline maintainer, bold in problem solving and so on. While females are labeled- weak in decision making, unable to maintain discipline, soft hearted, incapable in coordination, unable to manage time etc.

What makes someone stronger or weaker? What makes someone decisive or less decisive? What makes someone determined or hesitant? Such questions are related to human personality. Human personality is social construct and directly related to leadership roles. To understand and analyze the social behavior and leadership, I need the theoretical base.

In this paper I have selected two theories. First one is the "Radical feminist theory" and second one is "Symbolic interaction theory". The first theory will help me to understand the causes of gender discrimination, social perspective on gender, help me to analyze the female educational leaders' experiences that they had during their work and moreover this theory will help me to analyse self-perception of female educational leaders. The second theory will support me to describe the types of symbols the girls have and the types of interactions they do during their social life and effects on their social behaviour and attitude of these symbols and interactions.

\section{Feminism or feminist perspective}

Feminism explains the forms of inequality and oppressions that are created in the society. Gender discrimination and gender biasness is a product of the society and each society has certain forms of discriminations (Kaur, 2016). Feminism aims to reform the society and bring changes in it.

Feminism thus, not just the description of the forms of inequality, discriminations and gender biasness, it aims to reform the society and bring change and reduction of oppressions of all forms that has been taking place in the society. Feminist theories keep gender at the center of the study (Huilman \& Winters, 2016). Feminism analyzes the problem and challenges that female faces and oppressions that she bears and this theory raise voice against all the forms of discriminations and exploitation (Hooks, 2000).

There are some 'terms' that are associated with the feminism theory. Feminist, female, feminine, sex and gender are the terms that are to be cleared at first before discussing more on the theory of feminism. Moi (1989) aptly differentiates between three terms- feminist, female and feminine, which are rather considered as same. "The first is "a political position"; the second is "a matter of biology" and the third "a set of culturally defined characteristics" (as cited in Kaur, 2016, p. 1107).

Freedman (2001) differentiates the terms 'female' and' feminine'- 'female' as a physiological 'sex' and 'feminine' as a social 'gender'. So 'female' is natural phenomena and can be termed as 'sex' but 'feminine' is a social construct which can be termed as 'gender'.

During the period of development different feminist theories were emerged. "A basic version of this categorization would divide feminisms and feminists into three loose groups: liberal feminism, Marxist or socialist feminism, and radical feminism" (Freedman, 2001. p. 5). Liberal feminists focus themselves on equal right and power for females; Marxist and socialist feminists foster on labour rights and equalities in production and distribution and radical feminists analyze and find the causes of female oppression and domination as social system of patriarchy.

Hardiman and Jackson (2010) point out three levels of discrimination. The first level is individual where 
attitudes and actions that reflect prejudice against a social group. The second is institutional level where policies, laws, rules, norms, and customs enacted by organizations and social institutions that disadvantage some social groups and advantage other social groups. These institutions include religion, government, education, law, the media, and health care system and the third is societal/cultural level where social norms, roles, rituals, language, music, and art that reflect and reinforce the belief that one social group is superior to another.

Leadership role of females in educational institutions is decided indirectly by the society and patriarchic system of the society has stereotypic point of view towards females that is not seen supportive and friendly for them. The patriarchic system of society affects the laws, rules and policies. Even from the beginning of infancy boys and girls treated differently. As Freedman (2001) states, "The social roles and modes of behaviour that civilizations have assigned to women have kept them in an inferior position to that of men" (p. 14). Human behaviors, thoughts, life style, courage or daring, initiation, decision making, relationship making, risk bearing and so on are needed for leadership post and these qualities are developed from the environment of home and society but the society keeps females in inferior and dominant position since the childhood and leadership qualities are difficult to raise. I have analyzed this article mainly on the perspective of "radical feminism". Radical feminism has focused on exposing the worst excesses of the social system which is male supremacy (Thompson, 2001) and it argues that the patriarchic structure of our society is an obstacle for females to reach in leadership.

\section{The Perspectives of Symbolic Interactionism}

Mainly how females are nurtured from the early childhood and what behaviour and symbols they receive and how they internalize these matters in their thinking and doing is to be well understood by the researcher. So I am looking the society through the perspective of "symbolic interactionism".

Symbolic interaction theory has come from the works of the sociologists like John Dewey (1930), George Herbert Mead (1934), Charles Horton Cooley (1902), Robert Park (1864-1944)), and Herbert Blumer (1915).

Symbolic interaction theory believes that individuals guide themselves on the basis of symbols and interactions with peoples around them and all the objects and symbols do not give same meaning to them. Individuals' perception and understanding about the context differ the meaning. And what the individual thinks and perceive about the things/events he reacts on it (Aksan, Kisac, Aydin \& Demirbuken, 2009). Further Aksan et al. (2009) argue, "Meaning is created as a result of the interaction between people, and meaning allows people produce some of the facts forming the sensory world. These facts are related to how people form meaning" ( $p$. 903).

Spoken or written forms of language, signs, objects and other things that give meanings are symbols. These symbols are used in human interaction and the pattern or type of interaction builds or creates human personality and their behaviour. Aksan, et al. (2009) found-

In order to understand human behaviors, it is necessary to understand definitions, meaning and processes formed by humans first. Elements such as social roles, traditional structures, rules, laws, purposes, etc. provide raw material to the individuals for forming definitions. In this context, symbolic interaction stresses social interaction, debate of definitions and taking emphatic role between people ( $p$. 904).

Human beings create their own personality. What they experience, what they feel, how they perceived by others and how they make meaning are the factors of making the personality. In other words, the interaction with outer world is the process of personality development. It is a meaning making process about self and about others. That is why human personality is seen different. "Symbolic interaction is a process including the interpretation of actions because symbolic meanings might be formed differently for anyone" (Aksan et al.2009).

Gender is also a symbol that is created by the society. Gendered behaviour, gender discrimination, gender inequality, gender biasness, gender oppression, gender violence are different forms of symbolic interactions. These are the processes of socialization and social development. What girls feel, experience, see and know about self and others female, is all symbolic interaction. So symbolic interaction theory is an important theory to understand gender and sexuality that is in different forms in the society. Carter and Fuller (2015) found,-

Many have found symbolic interactionism useful for understanding the construction of gender and sexuality. West and Zimmerman's (1987) 'Doing gender' set the stage for social constructionist research on gender and sexuality. The concept of 'doing gender' demonstrates the socially constructed nature of masculinity and femininity as developing out of repeated, patterned interaction and socialization processes. The authors contend that gender emerges through interaction, directly contradicting the normative perspective of gender as an innate state of being or individual quality (Carter \& Fuller, 2015. p.7).

Roles and behaviour that an individual acquires from the society is through the symbolic interaction. So the gendered role or sexuality is the product of long practices of our society. From the early stage of development girls feel, interact and get experiences differently in homes, society, schools, peer groups and other places. These 
experiences play vital roles in future to perform leadership or other responsibilities in the society.

\section{Methodology}

The research is based on critical paradigm. Critical paradigm is not only to analyze the text it is to analyze the context too (Rogers, 2011). "Critical analysis of discourse is an analysis not only of what is said, but of what is left out; not only what is present in the text, but what is absent" (ibid. P. 15). Critical paradigm challenges the inequalities, social unjust, policies, practices, domination, oppressions etc. that are in the field of education (Mack (n.d.), Taylor \& Medina, 2013 \& Dammak, 2015). My intention in this research paper is also to analyze and challenge the practices and customs that are in our schools and society deeply rooted. My aim here is to watch, analyze and raise questions against the texts and context.

My aim here is to share the experiences of female educational leaders, find out their socio-cultural challenges, and to analyze the gender perspective they felt. So I have used purposive sampling. For this, I have selected two experienced and successful principals- one from private school and another from public school in Bhaktapur district. At first I collected information of those principals from resource centre. Then I phoned both of the principals and requested them to help me and got time for meetings. I prepared some guiding questions for the interviews.

I told them my background, my teaching journey and purpose of the interviews. Next day I met principal ' $\mathrm{A}$ ' and interviewed and discussed on the issued and challenges that she experienced during her long journey from teacher to principal. I recorded her voices in an audio-tape from her permission. I applied the same procedures another day to interview principal ' $\mathrm{B}$ '.

First I transcribed the voice records (interviews) into written symbols, and then I put the transcriptions into different codes and finally I prepared some themes. I used the main themes as the topics for further discussion on the basis of some theoretical bases and I concluded the discussion at last.

\section{Discussion and Findings}

Gender and leadership differences are common phenomena. Biologically males and females are different but social behaviour, attitudes; perceptions about self and perception about outer world are not natural phenomena. These are the results of different experiences and social behaviour by gender. The causes of such difference are discussed here on the perspective of radical feminism and symbolic interactionism. The discussion is divided mainly in two parts. The first is focused on the causes of different nature/character of male and female and the second is concerned on the challenges of female principals.

\section{What Makes Males and Females Different?}

The biological differences between male and female is not the main cause of the construction of different character. The occurrence of different nature of male and female is social construct. Giving birth of a child and breast feeding is not the cause of different characteristics (Freedman, 2001). The biological weaknesses of female are not the main cause that makes them different (Kaur, 2016). It is social behaviour that makes them weaker and inferior than males. Further discussions are on this topic is divided on following sub topics.

\section{The 'Safe-zone' Concept}

From the very beginning of childhood girls are kept in 'safe-zone'. Boys are allowed to go outside while girls are kept inside the home in the name of security. They are allowed to go outside with other males or adults. This safe-zone concept makes them weak and less confidential. Later this concept plays a vital role in whole life. In symbolic interaction perspective, this helps females to make meaning about self and get certain self perception. They psychologically become weaker. In my study, principal 'A' argued on this concept interestingly. She said-

I was the eldest child of our family. I remember, my mother usually became sick and had to be hospitalized time to time. I had to go hospital, look after my brothers and sisters, and help my father. Usually I had to go alone for shopping. Such responsibilities slowly made me self confidential and bold. I was never kept in safe zone. Usually parents want to keep their daughter in safe-zone and this makes them weaker and dependent. I think the main cause of being a principal is my childhood experiences.

This story fits with the perspectives of symbolic interaction. The interaction with the outer world helps individual in meaning making about self and the objects. Whatever an individual perceive and experience, makes her personality. In our patriarchic society females are dominated from the childhood, they are labeled weak and treated differently which cause different personality. That is why females are seen weaker, soft hearted, weak in decision making and unable to co-ordinate out sides.

\section{Wrong Orientation to the Girls since Childhood}

The aims of education are created differently for boys and girls by the family. Boys are told to study hard to earn money, name and fame but girls are oriented to study hard to get Ramro Keto (good bridegroom) and ramro 
ghar (good home of husband). This misconception misguides the girls from the childhood. They are never told to get higher education for good carrier, better profession and self-dependent. Principal " $A$ " shared her experiences-

When I was in primary level, I used to go mamaghar (maternal uncles' home). My grandmother and aunty used to say- "Ramrari padhnu hai nani, ramro padheu bhane ramro keto ra ramro ghar pauchheu. Hoina bhane ramro keto paudainau" (Study hard sweet heart! If you study hard, you will get good bridegroom and good home, otherwise you will not get good husband). I usually heard these types of saying and I used to be confused, how good study would help me to get good bridegroom.

The experience above clearly indicates that girls do not get clear directions in making future aims. They are oriented wrongly and these types of wrong orientations lead them towards wrong way. The meaning making process (Aksan et al. 2009) of life differ girls than the boys. They are not told to get higher education for better carrier and better future. As Kaur (2016) describes, "Man is considered responsible for earning the money whereas woman is assigned the duty to look after the family and the household" (Kaur, 2016. p.1108). The symbolic interaction misguides them and they are regarded to study for serving the husband in future. It is because of the patriarchic social values and norms.

Human personality is constructions of the experiences, feelings, behaviour of others and self perception. Girls get all these differently than boys. These factors make the girls personality different than the boys. If females are psychologically weak, soft hearted, less determinant, lack of risk taking behaviour and unable to deal with outer world, it is because of the system they were nurtured. It is because of the inferior position in society and discrimination encountered by females because of their sex (Freedman, 2001). The position is started to create in their homes, schools and surroundings. It is not the product of biological differences it is the product of gender differences which is created by the society.

\section{Female Principals and Leadership Challenges}

Female principals experienced different challenges and problems during their carrier development. It is because of stereotypic assumptions of male dominated society. It is because of the mindset of men towards females so the problems are not natural but socially constructed. Some of the challenges and problem that female principals experienced are discussed in following topics.

\section{Masculine Style of Leadership}

Nearly all the history of human civilization is male leaded. So leadership is known as the masculine natured and taken "think male, think leader" (Hillier, 2012) stereotype. If some females get chance to perform the leadership roles, they are assumed to play the masculine roles. This "double bind dilemma" (ibid.) is seen problematic to the females. Naturally the environment that the females get makes them different from males. Females seem more democratic, participative and collaborative and they are more nurturing and less autocratic (Burdick \& Danzig, 2006). But they are expected as male nature but to change the nature is too much difficult. Principal ' $\mathrm{B}$ ' shared me her experiences on the issue. In her words-

I have been working in this school for thirty-five years and for eight years I was working as assistant principal. When my turn came for principal-ship school management committee was seen a little bit hesitant because the school was male headed and they thought that I would not able to keep discipline. Discipline for them is rigorous and fear making process. Being a female they thought that I will not do that. It was really challenging. Finally they appointed me in the post.

Principle 'A' also shared her experiences but her experiences were little bit different. She also forced to show male character by punishing the children. She said-

When I bought this school, it was run by a male principal. This school was known as a place of punishment to students. The name of the school is Siddartha Vidya Pith but that time it was called Siddrath vidyarti pit (school to punish students). I was trying to change the image of the school and I wanted to create child friendly environment. One day some guardian of children came and told me- "we have heard that you distribute chocolates to the children. We have send children here for discipline and learning not for chocolates. You have to beat the children in front us". I was perplexed, what to do. Then I called their children inside my office and brought a big stick (she brought a stick and showed me), you know, this is eighteen years old stick and my history, and I told the guardians to stay outside and started to hit the sofa with full strength. The children started to cry loudly. They thought that I was hitting their children. They became happy and returned back.

The interesting stories clearly show that society wants school principal as a masculine nature. It is thought that successful principal must have the nature of male. Female nature cannot be useful to run the institutions successfully. This is too much challenging for females. Principal 'A' further shared her story on how she changed the perceptions of the parents. She said-

It was most difficult me to change the parents opinions on so-called discipline. Finally I found a trick. 
One day I organized a speech programme in the school. I requested my 'Guru' to address the parents on 'child punishment and its impact'. I called all parents in school, manage breakfast and lunch for them and they heard whole speech of the Guru. It worked surprisingly, and since then on one told me to punish their children. Now the school is fully child friendly.

This journey of the principal is really inspiring but the entire principals might not so tactful and might face problems in the school management. As discussed earlier, the nature of female is the construction of the social environment that they get since their childhood. The interaction, perception, understanding, feelings etc. are the result of symbolic interaction that they get, internalize and make their own personality.

\section{Social Consent and Approval}

Because of patriarchic social structure and socio-cultural stratum, females have to proof themselves that they are compatible, capable and skilled to run the school, whereas their male counterparts need not to do so because they have already got the trust of being male. This social reality creates challenges for females. The society has already worn the 'glass of stereotype' that shows males and females different.

In this study both principals have the bitter experiences on this issue. They had struggle hard to proof themselves as competent as males. Principal 'A' told her story as follow-

Usually parents come here and ask me whether I have trainings or not and whether I have any skills or not. I have to show them my training certificates them. (Pointing out at the display board) Look that display board and cupboard! These are my certificates of different trainings, and the medals and trophies that I received in different events. I started to display all these and now I need not to explain, I just show them the boards. But if I were a male I would not proof myself in this way.

Above experience is a clear example of gender discrimination on educational leadership. Social perspective about females is still in existence in different forms. To face the challenge females feel difficulties in real life. It is discouraging and disappointing phenomena that females are facing.

\section{Family Support and Time Management}

To be the school principal, family support is mostly needed. Success and failure in that post depends in some extent on family coordination and cooperation. If females have to do all the household activities and perform all responsibilities of children, husband and other family members, it becomes really worse to them.

Family responsibility limits the mobility of the females and it becomes a barrier to them (Leatherwood \& Williams, 2008). Engagement in family responsibilities caused females loss of the social network (Hillier, 2012; Sandra \& Sandra, 2007). This creates obstacles in their carrier. The nature of our society and family structure is not much favorable for women. Males returned tired and get rest in the homes, while females go for work tired, returned back from work tired and more tired in the household works instead of having rest. This is because of patriarchic structure of the family.

In this study both of the participants shared nearly the same experiences in time management and family support. Although they did not directly accept that their family is unsupportive but the meaning was the same. Principal 'A' shared her experiences as-

Time management for females is really challenging. Although I am a grandmother now and I do not have to give much time in household activities, yet I have to give time to my family. If I become late for home my grandson started to call me. And because of lack of time I am unable to accept the responsibility of president of PABSON. Many times they offered me that post.

Principal 'B' also shared her experiences on this issue. She told-

I am unmarried so I don't have the responsibilities of children and spouse but I have to look after my old parents. Because of lack of time, I am unable to coordinate the donor agencies that can help the school.

These discussions show that female principals have problems in time management. Time management is deeply associated with family support. If the family supports them, time management would be easier. But the structure of the family and the society is not supportive and helpful for females. So, educational leadership is being more challenging and difficult to them.

\section{Conclusion}

Leadership difference by gender is a reality not a dilemma. The causes behind it are many but mainly gender based behaviour, orientation and education of society are the main causes. Gender discrimination, gender biasness and gender stereotypic thinking are common factors which create barriers in the progress of the females (Abdulkareem, Saeed, Umaru \& Yekeen, 2011; Bista, 2006; Bista \& Carney, 2001; Helterbran \& Rieg, 2004; Hoff, Menard \& Tuell 2006). Patriarchic structure of society and male dominated culture is wide spread characteristics which keep females differ to males (Thompson, 2001). Females are different biologically and physically than males and vice-a versa. But these differences are not problematic. Problems are in male's 
behaviour and attitudes. Freedman's claims are notable here, he says, "woman is a biological and not a sociohistorical category, even though all the behaviour associated with femininity is clearly a social construction" (Freedman, 2001, p. 14). Thus, problem is in the male dominated society, not in females' behaviour and ability.

As Hillier (2012) argues, females working styles are affected from the 'glass ceiling concept'. The concept asserts that females create certain level of ceiling for themselves and this ceiling limits them to go upper level. This is also an effect of social symbols and interaction.

The factors that make females different are the processes of socialization and system of the society. Social behaviour, attitudes, concepts and perspectives make females different. As Hardiman and Jackson (2010) claimed the difference created in three levels, one of them is family. The family starts to discriminate between boys and girls that leave long term effects psychologically and socially. The differences are seen in females' behaviour, self perception, understanding, attitudes and activities which is the result of socially constructed. Carter and Fuller (2015) name it 'doing gender'. They says, 'the concept of 'doing gender' demonstrates the socially constructed nature of masculinity and femininity as developing out of repeated, patterned interaction and socialization processes" (Carter \& Fuller, 2015, p. 7). So gender difference is naturally seen in educational leadership which is the product of the society that results from the social process.

Leadership difference is seen in males and females. It is the product of social behaviour. Since the childhood boys and girls are oriented and trained differently even carrier choice and interest depend on such orientation (Barbulescu \& Bidwell, n.d.). Later different system of nurturing occurs in their behaviour. In professional carrier this is seen in different forms and patterns. From the perspective of feminism it is the result of gender discrimination and dominating behaviour.

In this study I found that a gender difference in educational leadership is the effect of social interaction. Theoretically symbolic interactionism and gendered behaviour are closely related to each other (Aksan et al. (2009). Gender discrimination, gender biasness, gender stereotype and male domination are the social symbols that the girls feel, realize and experience from the beginning of life and the interactions with the society make their personality. Because individuals make sense of their world from their unique perspective that they receive from social interactions (Carter \& Fuller, 2015). The different personality naturally differentiates the working style and behaviour. As Freedman (2001) argued, "women will never share power with men because they lack men's genes for competitiveness and risk-taking behaviour" (Freedman, 2001, p. 13). Here power denotes physical power which may be genetic product but mental and psychological power is the product of environment, which is risk-taking and competitiveness.

In this study it is experienced that females have unique challenges in the post of principal. Mainly they had to apply masculine nature of leadership role; they had to proof themselves as successful and competent principals, they had to manage time; they had to perform double and triple duties (Yamasita \& Yamasita, 2000) and they had to work in challenging environment. the environment of males. Females are created 'females' because they are known as the second level persons.

To make the world 'world for all' and to create the society equitable, female empowerment is needed. In my opinion it should be started from the homes and started from the beginning of childhood. Boys and girls should be treated equally and should be provided equal opportunity and equal experiences. 'Safe -zone concept' makes girls weaker and dependent, so they should have given experiences of 'danger-zone'. The experiences of 'danger zone' help them to be stronger and competent. The society needs strong girls as well as strong boys. Sameness in behaviour and experiences make both sexes same in feeling and same in acting.

\section{References}

Adkinson, J. (1981). Women in school administration. A Review of Educational Research. .51 (3). American Research Association. 311-343. Retrieved from http:// www.jestor.org/stable/1170201

Aksan, N.; Kisac, B.; Aydin, M. \& Demirbuken, S. (2009). Symbolic interaction theory. Procedia Social and Behavioral Sciences 1. 902-904. doi:10.1016/j.sbspro.2009.01.160

Barbulescu, R., \& Bidwell, M. J. (2013). Do women choose different jobs from men? Mechanisms of application segregation in the market for managerial workers. Organization Science, 24(3), 737-756. http://dx.doi.org/10.1287/ orsc. 1120.0757

Bista, M. \& Carney, S. (2001). Capacity building for educational improvement: An institutional analysis of the Ministry of Education and Sports. Kathmandu: MOE.

Bista, M. (2006). Status of female teachers in Nepal. Kathmandu: Unesco

Burdick, D. \& Danzig, A. (2006). Teacher ratings of principal applicants: The significance of gender and leadership style. Journal of Women in Educational Leadership, 4 (1). 21-42. Retrieved from https://digitalcommons.unl.edu/cgi/viewcontent.cgi? article $=1177 \&$ context $=j w e l$

Carter, M. \& Fuller, C. (2015). Symbolic interactionism. Sociopedia.isa. 1-17.DOI: 10.1177/205684601561

Coleman, M. (1996). The management style of female head teachers. New Delhi: Sage Publication.

Crosby-Hillier, K. (2012). Women and educational leadership: Exploring the experiences of current and aspiring 
female educational administrators. Electronic Theses and Dissertations. 243. Retrieved from https://scholar.uwindsor.ca/cgi/viewcontent.cgi? article $=1242 \&$ context $=$ etd

Dammak, A. (2015). Research paradigms: Methodologies and compatible methods. 1-14. Retrieved from www.stclements.edu/Articles/Research-Paradigms-Full-Article.pdf

Freedman, J. (2001). Feminism. Open University Press Philadelphia: Retrieved from https://www.mheducation.co.uk/openup/chapters/0335204155.pdf

Hardiman, R. \& Jackson. B. (n.d.). Conceptual framework for oppression: Conceptual foundation for social justice courses. 16-29. Retrieved From

www.webpages.uidaho.edu/.../Conceptual\%20Framework\% $\% 20$ for $\% 20$ Oppression.pdf

Helterbran, V. R. \& Rieg, S. A. (2004). Women as school principals: What is the challenge? Journal of Women in Educational Leadership, 2 (1). 12-21. Retrieved from $\mathrm{http}$ //digitalcommons.unl.edu/cgi/viewcontent.cgi?article=1113\&context=jwel

Hooks, B. (2000). Feminism is for everybody. South end press Cambridge. Retrieved from https://excoradfeminisms.files.wordpress.com/2010/03/bell_hooks-feminism_is_for_everybody.pdf

Jackson, S. \& Harris, S. (2007). African American female college and university presidents: Experiences and perceptions of barriers to the presidency. Journal of Women in Educational Leadership,7. 119-138. Retrieved from http://digitalcommons.unl.edu/jwel/7

Ropers-Huilman, R. \& Winters, K. T. (2016). Feminist research in higher education. The Ohio State University Press, 82. 667-690. Retrieved From https://doi.org/10.1080/00221546.2011.11777223

Kaur, R. (2016). Feminism: Introduction and aims. Imperial Journal of Interdisciplinary Research (IJIR), 2 (6). 1107-1109. Retrieved from https://www.onlinejournal.in/IJIRV2I6/207.pdf

Kusar, D.; Altunay, E. \& Yalcinkaya, M. (2014). The difficulties of female primary school administrators in the administration process and solution suggestions: Education Sciences: Theory and Practices. Educational Consultancy and Research Center.14 (3). 905-919. Retrieved from https://files.eric.ed.gov/fulltext/EJ1034093.pdf

Leatherwood, L., \& Williams, M. (2008). Gender and career paths. Journal of Women in Educational Leadership. 15. 261-275. Retrieved from http://digitalcommons.unl.edu/jwel/15

Mack, L. (n.d.). The philosophical underpinning of educational research. Polyglossia, 19. 5-11.Retrieved from en.apu.ac.jp/rcaps/uploads/fckeditor/publications/.../Polyglossia_V19_Lindsay.pdf

Mohajery, B.; Mokhtar, M. \& Balash, F. (2015). Challenges encountering of participation of women in senior administrative status in higher education. International education studies 8 (13), 9-16. Retrieved from http://www.ccsenet.org/journal/index.php/ies/article/view/50357

Rogers, R. (2011). An introduction to critical discourse analysis in education. Routledge. NY: Retrieved from https://www.google.com/search?client=firefox-bab\&q=Rogers \%2C+R.+\%282011\%29.+An+introduction+to+critical+discourse+analysis + in + education.+

Taylor, P.C., \& Medina, M.N.D. (2013). Educational research paradigms: From positivism to Multiparadigmatic. Journal for Meaning Centered Education, 1. 1-16. . DOI: 10.13140/2.1.3542.0805

Thompson, D. (2001). Radical feminism today. SAGE Publication. London: Retrieved from https://we.riseup.net/assets/362574/Radical+Feminism+Today+Denise + Thompson.pdf

Yamasita, Y. \& Yamasita, T. (2000). Bringing education to girls in remote areas of Nepal: Report of field research conducted in the five development regions of Nepal. Kathmandu: UNESCO. 